\title{
The Roma vaccination gap: Evidence from twelve countries in Central and South-East Europe
}

\author{
Laetitia Duval' François-Charles Wolffi Martin McKee ${ }^{\text {iii }}$ Bayard Roberts ${ }^{\text {iv }}$
}

\author{
September 2016 \\ Second revision, Vaccine
}

\begin{abstract}
Aim: To investigate differences in vaccination coverage between Roma and otherwise comparable non-Roma children, including factors associated with the vaccination gap, health care access and discrimination faced by Roma.

Methods: We analyse data from the Roma Regional Survey 2011 implemented in twelve countries of Central and South-East Europe. Our sample comprises 8,233 children aged up to 6 with 7,072 Roma children and 1,161 non-Roma children. Estimates of the Roma vaccination gap are estimated using Logit regressions.
\end{abstract}

Results: We find that the Roma children have a lower probability of being vaccinated compared to non-Roma (odds ratio $=0.325$ ). The odds of being vaccinated for a Roma child is $33.9 \%$ that of a nonRoma child for DPT, 34.4\% for Polio, 38.6\% for MMR and $45.7 \%$ for BCG. These differences do not appear to be explained entirely by their worse socio-economic status. The ethnic gap narrows by about $50 \%$ once individual characteristics are controlled for, with odds ratios of 0.548 for DPT, 0.559 for Polio, 0.598 for MMR and 0.704 for BCG. The probability of being vaccinated increases with access to health care, especially when Roma have a doctor to approach when needed.

Conclusions: Our findings point out a large difference in vaccination coverage between Roma and non-Roma and support the need for better understanding of factors influencing vaccination among Roma as well as policies that might improve services for Roma in Central and South-East Europe.

Keywords: Vaccination, immunization, Roma, ethnicity, discrimination, Central and South-East Europe

\footnotetext{
i Corresponding author. School of Public Health, Imperial College London, St Mary's Campus, Norfolk Place, London W2 1PG, United Kingdom. E-mail: I.duval@imperial.ac.uk

ii LEMNA, Université de Nantes, BP 52231 Chemin de la Censive du Tertre, 44322 Nantes Cedex, France and INED, Paris, France. E-mail: francois.wolff@univ-nantes.fr

iii ECOHOST - The Centre for Health and Social Change, Faculty of Public Health and Policy, London School of Hygiene and Tropical Medicine, London, United Kingdom. E-mail: Martin.McKee@lshtm.ac.uk

iv ECOHOST - The Centre for Health and Social Change, Faculty of Public Health and Policy, London School of Hygiene and Tropical Medicine, London, United Kingdom. E-mail: Bayard.Roberts@Ishtm.ac.uk
} 


\section{Introduction}

The Roma are the largest, poorest and youngest ethnic minority group in Europe (estimated to number 10-12 million), most living in Central and South-East Europe ${ }^{1}$. Their origins are in Northern India, in what is now the Punjab, from where they moved westwards around 1000 AD. They have long been subject to persecution; many were kept as slaves in parts of what is now Romania until the nineteenth century and large numbers perished in the Holocaust ${ }^{12}$.

Despite living in Europe for at least 700 years, many remain on the margins of society, physically, in distinct settlements, administratively, being denied citizenship and identity documents, and socially, for example with children educated separately. They suffer multiple disadvantages, with lower education, unemployment and worse living conditions 234 . Despite receiving unprecedented attention in the process of European Union enlargement from both the media and policy makers, research on health of Roma is still very limited, and in particular for children ${ }^{5-8}$. Roma experience lower life expectancy and higher rates of several communicable and non-communicable diseases than the majority population ${ }^{78}$. The reasons are complex and include widespread discrimination in employment, education and access to health care.

Concerns about the multiple disadvantages faced by Roma led to the implementation of the Decade of Roma Inclusion, which brought together national governments, international agencies and civil society and operated between 2005 and $2015^{3}$. Together, the participants invested in areas such as housing, education, social welfare, and health. However, as signified by the sub-title of the final report, "a lost decade", it achieved much less than had been promised ${ }^{9}$. Most progress was made in education, in particular tackling the segregation of Roma children but, as the evaluation noted, the initiative was unable to overcome the powerful impact of racism and discrimination.

This paper explores one of many issues affecting Roma, immunisation against common childhood diseases. Several outbreaks of measles among Roma have been linked to low levels of immunisation 1012 and this has assumed a wider importance as Europe moves towards eradication of measles. Moreover, because of their disadvantage and corresponding risk of micronutrient deficiency, Roma children may be at particular risk of complications if they contract diseases such as measles ${ }^{14}$. Yet there is little research on the factors associated with immunisation among Roma, in part because of a lack of appropriate data in this hard to reach population ${ }^{1}$. What research does exist focuses on one or a few districts in a single country, often with a very small number of observations ${ }^{14}{ }^{15}$ and authors have repeatedly noted the importance of achieving a better understanding of this issue ${ }^{16-18}$. We investigate differences in child vaccination coverage between Roma and non-Roma living in proximity to them, seeking to understand determinants of the vaccination gap, including access to health care and discrimination faced by Roma. To the best of our knowledge, our study is the first to report comparative data from several countries to understand the scale of the unmet need for 
immunisation among Roma. It takes advantage of a unique internationally comparable data set covering countries in Central and South-East Europe, where $80 \%$ of all European Roma live and where Roma comprise a substantial and increasing share of the overall population ${ }^{1}$.

\section{Methods}

$\underline{\text { Data }}$

We use data from the Roma Regional Survey, a cross-sectional household survey commissioned by the United Nations Development Programme, the World Bank and the European Commission ${ }^{1920}$. The survey was conducted from May to July 2011. The sample comprises both Roma $(N=7,072)$ and non-Roma $(\mathrm{N}=1,161)$ households living in countries with high proportion of Roma, namely Albania, Bosnia and Herzegovina, Bulgaria, Croatia, the Czech Republic, Hungary, Macedonia, Moldova, Montenegro, Romania, Serbia and Slovakia.

In each country, approximately 750 households in Roma settlements were identified. The comparison sample was selected to be as similar as possible to the Roma sample, except for their ethnicity, given the material disadvantage and geographical marginalisation of Roma living in settlements. Consequently, 350 non-Roma households living in the same neighbourhood (defined as households living in close proximity, within 300 meters, of a Roma settlement) were selected. A stratified cluster random sampling design was used. The method of data collection was face-to-face interviews at the respondent's household. The overall sample comprises 54,660 persons of all ages with 41,334 Roma and 13,326 non-Roma, corresponding to 13,481 households (Table 1).

[Insert Table 1]

Questions dealing with vaccination coverage are in the second module of the Roma Regional Survey about early childhood education and care. As they concern family members being 6 years old and younger, we exclude individuals older than 6 from our sample. Overall, our sample comprises 8,233 children up to 6 years of age which are the units of observation (7,072 Roma and 1,161 non Roma), corresponding to 5,115 families (4,241 Roma and 874 non Roma). Thus, we have multiple young children for some families: $62.1 \%$ of them have one child, $27.0 \%$ two children, $8.3 \%$ three children and $2.6 \%$ four and more. The proportion of Roma children up to 6 years of age ranges from $78.2 \%$ in the Czech Republic to $91.1 \%$ in Croatia (Table 1).

The survey questionnaire covers demographic characteristics, education, employment status, living standards, social values and norms, migration, discrimination and health. All vaccination questions were administered to the child's primary carer. First, the primary carer is asked whether the child has received any vaccinations: "Did [name] ever receive any vaccinations to prevent him/her from getting diseases?". Then, questions were asked about the type of vaccination received: "1/ A BCG vaccine against tuberculosis, that is, an injection in the left arm or shoulder that usually causes a 
scar?; 2/ Polio vaccine, that is, drop in mouth, which is given for child paralysis? ; 3/ DPT (DiTePer) vaccination, that is, an injection in the thigh or buttocks to prevent tetanus, whooping cough, or diphtheria? ; 4/ MMR injection to prevent measles, that is a shot in the arm at the age of 9 months or older?". Possible answers are yes or no. For Polio, DPT and MMR, there is additional information about the number of time the child received the vaccine.

\section{Statistical analysis}

A Logit regression is used to explain the probability that a child is vaccinated. Additional Logit regressions are also estimated for each type of vaccine (BCG, Polio, DPT, MMR). The results are reported as odds ratios with 95 percent confidence intervals for being Roma, our main variable of interest. In the various regressions, standard errors are clustered at the family level since a family can contribute to several observations in the sample ${ }^{21}$. To isolate as far as possible the role of ethnicity (Roma origin), we account for the following individual characteristics of the child: gender, age, possession of a birth certificate. The following individual characteristics of the primary carer were accounted for: gender, age, marital status, household size, education level, occupation and location. We use data on asset ownership to construct a proxy for household cumulative economic status. Specifically, we aggregate a set of asset ownership indicators into one asset index using a principal component analysis ${ }^{22}$. The items included in the index were radio receiver, colour TV, bicycle or motorbike, car/van for private use, horse, computer, internet connection, mobile phone or landline, washing machine, bed for each household member including infants, thirty and more books except school books, and power generator. The principal component technique is implemented on the whole sample of Roma and non-Roma individuals. By construction, the average of the asset index is set to zero (the standard deviation of 1.84). Higher values for the asset index correspond to higher long-run socioeconomic status.

To examine determinants of vaccination coverage further, we accounted for the role of health care access and discrimination. To do so, we used the following three questions: $1 /$ "does your household have a doctor to approach when needed?"; 2 / "do you feel safe in regard to health protection - do you have the confidence that you will receive service in case you need it?"; and 3/ "were there any instances in the past 12 months when your household could not afford purchasing medicines prescribed to, needed for a member of your household?". We also included in our regressions variables from a specific section about general discrimination and rights awareness. Discrimination is defined as being treated less favourably than others because of a specific personal feature such as age, gender or minority background. We rely on answers to the following question: "during the last five years, have you ever been discriminated against by people working in public or private health services? That could be anyone, such as receptionist, nurse or doctor." The reason for the 
discrimination is specified: it can be either discrimination on the basis of ethnic background or discrimination because of other reasons.

\section{Results}

Sample characteristics

Characteristics of the samples are reported in Table 2. The proportion of girls among Roma children and non-Roma is similar (around 0.50). Roma children are slightly younger on average and the proportion of Roma children with a birth certificate is slightly lower (-1.2 percentage points). Several characteristics of the primary carers also differ. Roma carers are on average younger (almost 2 years), they belong to larger households (6.2 persons compared to 4.8 for non-Roma), they are less educated (the proportion with a level upper / post-secondary education is $\mathbf{5 2 . 2}$ points lower for Roma) and they are less likely to have a paid activity or be self-employed (-18.1 points). Unsurprisingly, the average score for the asset index is much lower for Roma $(-0.311)$ than for nonRoma (1.896). Roma are more likely to live in a village or unregulated area.

\section{[Insert Table 2]}

Figure 1 shows the vaccination coverage (whatever the type of vaccines) by country for the pooled sample of Roma and non-Roma. Vaccination coverage of children up to 6 years old is on average 93.1\% for the twelve countries included. However, there is substantial heterogeneity. While it is lower in Bosnia and Herzegovina (83.4\%), Slovakia (90.3\%) and Albania (90.8\%), it exceeds $95 \%$ in the Czech Republic (95.3\%), Croatia (96.8\%) and Hungary (98.8\%).

\section{[Insert Figure 1]}

Table 3 shows the gap between Roma and non-Roma in vaccination by type of vaccines. When pooling all countries, we find significant differences between Roma and non-Roma $(p<0.01)$. The probability of having received any vaccination is 5 percentage points lower for Roma. The prevalence differential is higher for DPT vaccine (-20.4 points), MMR vaccine (-19.7 points) and Polio vaccine (-19.2 points) than for BCG vaccine (-10.6 points). The ethnic differential is 10.7 percentage points when considering the probability of having received either DPT, MMR, Polio or BCG, but it amounts to -20.3 percentage points when considering all four vaccine types.

\section{[Insert Table 3]}

There are also substantial differences between countries. When considering the probability of having received any vaccination, there is no Roma gap in Bulgaria, Hungary, Moldova and Slovakia, but there is a significant difference in all other countries, especially in Bosnia Herzegovina (-14.8 points) and in Albania (-10.5 points). With BCG vaccine, Roma are marginally, but non-significantly advantaged in Hungary (+1.1 points) but the disadvantage is greatest for Roma in Bosnia and Herzegovina (-21.2 points) and Romania (-21.2 points). For the DPT vaccine, the differential is highest in Bosnia and 
Herzegovina (-33.9 points) and lowest in Slovakia (-7.6 points). The largest gaps in MMR vaccine are found in Bosnia and Herzegovina and Romania. Finally, the gap exceeds 30 points in Bosnia and Herzegovina Czech Republic for all four vaccine types (DPT, MMR, Polio, BCG).

\section{Associations with being vaccinated}

We investigate the associations with vaccination coverage in Table 4 using Logit regressions. We pool both Roma and non-Roma samples of children and introduce in our regressions a dummy variable which is equal to one when the respondent is of Roma ethnicity (and zero otherwise). Without covariates (panel A), we find that the marginal effect associated with Roma status is negative and significant $(p<0.01)$ for all types of vaccine. They correspond in fact as the gap obtained by mean comparison tests reported in Table 3. A Roma child is only a third as likely to be vaccinated with all vaccines as a non-Roma child (odds ratio $0.325,95 \% \mathrm{Cl}=0.214-0.492$ ), with similar figures for individual vaccines: DPT (odds ratio $0.339,95 \% \mathrm{Cl}=0.279-0.410$ ); Polio (odds ratio $0.344,95 \% \mathrm{Cl}=$ 0.283-0.418); $\mathrm{MMR}$ (odds ratio $0.386,95 \% \mathrm{Cl}=0.325-0.458$ ); and a slightly narrower gap for $\mathrm{BCG}$ (odds ratio $0.457,95 \% \mathrm{Cl}=0.367-0.418$ ).

[Insert Table 4]

We then examine the role of individual characteristics as well as countries in explaining vaccination coverage (panel B). Controlling for differences in the child and their carer's characteristics reduces substantially (by around $50 \%$ ) the influence of ethnic status, which remains nonetheless statistically significant for the various outcomes. The odds of being vaccinated for a Roma child is now 0.527 compared with a non-Roma child for any vaccine $(95 \% \mathrm{Cl}=0.329-0.846), 0.548$ for DPT $(95 \% \mathrm{Cl}=$ 0.433-0.695), 0.559 for Polio ( $95 \% \mathrm{Cl}=0.440-0.710), 0.598$ for $\mathrm{MMR}(95 \% \mathrm{Cl}=0.481-0.744), 0.704$ for BCG $(95 \% \mathrm{Cl}=0.537-0.923)$ and 0.585 for all four vaccine types $(95 \% \mathrm{Cl}=0.478-0.716)$.

Many covariates such as possession of a birth certificate and the carer's age, education, asset index and living in a town are positively associated with the likelihood of being vaccinated. However, the carer being single, a homemaker or not working are significantly and negatively correlated with the probability that the child has received any vaccination (column 1). When comparing the estimates obtained separately by types of vaccine (columns 2 to 5 ), the correlation between vaccination coverage and age, birth certificate, education as well as asset index have the same negative sign.

\section{Vaccination, health care access and discrimination}

In Table 5, we introduce additional covariates related to access to health care and to discrimination. These additional controls do not affect the marginal effect obtained for the Roma dummy in the various regressions. We find that vaccination is more likely when respondents report they have a doctor to approach when needed (the odds ratios are 2.006 for any vaccination, 2.085 for DPT and 1.760 for MMR) or when they feel safe regarding health protection (the odds ratio is 1.414 for Polio and 1.274 for BCG). The inability to purchase medicines prescribed has no influence, except for BCG 
$(p<0.01)$ and Polio vaccines $(p<0.1)$. We also find a negative correlation between discrimination because of ethnicity and the probability of having received any vaccination and for DPT vaccine ( $p<0.05$ in both cases). The coefficients are also negative for BCG, Polio and MMR vaccines, but not significant.

[Insert Table 5]

\section{Discussion}

In this paper we compare patterns of vaccination of Roma with those of an otherwise comparable sample of the majority population in twelve countries of Central and South-East Europe. We examine four different vaccinations for children less than 6 years of age - the BCG vaccine against tuberculosis, IPV against polio, DPT against diphtheria, tetanus and pertussis and MMR against measles, mumps and rubella. All these diseases can be prevented by inexpensive vaccines, making immunization a public health priority for the region. The strengths of this study lie in the use of a large study sample across multiple countries providing new comparative empirical evidence on Roma vaccination coverage.

Our findings show that Roma children are less likely, on average, to have received any vaccination compared to non-Roma (with substantial heterogeneity among countries). The Roma origin remains statistically significant once family characteristics and countries are controlled for in the Logit regressions. The probability that a Roma child will be vaccinated is about $55 \%-60 \%$ that of a nonRoma child for DPT, Polio and MMR.

This study adds to the broader literature on the determinants of health and health seeking behaviour, and specifically the importance of race versus class. This literature has been especially prominent in the USA, with Wilson, in the late 1970s, arguing that social class was displacing race as the leading determinant of the life chances of African Americans ${ }^{23}$, although this view is heavily contested ${ }^{24}{ }^{25}$. This literature has given rise to the concept of intersectionality ${ }^{26}$, especially in gender studies where scholars have examined the interaction between gender, race and class among other factors. This approach is beginning to be used in Roma studies ${ }^{27-29}$, although so far to a very limited extent in relation to health.

The importance of an intersectionality approach is that it shows that differences in vaccination coverage cannot simply be explained by the worse socio-economic situation of Roma. First, the comparison with non-Roma population comprises those living in close proximity to Roma settlements and not the general population. This means that our data presumably underestimate the overall gap between the Roma and non-Roma population in each country. Second, the ethnic gap remains substantial even when accounting for a wealth index which is a relevant proxy for measuring long-term socioeconomic status ${ }^{22}$. 
We also find a positive correlation between the probability that a child received any vaccination and access to health care as reported by Roma, especially in relation to having a doctor to approach when needed and feeling safe regarding health protection. This is consistent with a large body of work showing physical, economic, and discriminatory barriers to obtaining care experienced by Roma in many countries 5 .

For unvaccinated children, there is one additional question indicating why children did not receive vaccination. For those who have no vaccine at all, the main reason reported by the caregiver is the unawareness of need for any immunization (21.5\%). This motive is much more frequent among Roma $(21.9 \%)$ than among non-Roma (13.3\%). The proportions of other motives (without any indications) or unknown answers are also substantial (13.3\% and 14.4\%, respectively). Among Roma, 9.2\% could not afford or did not want to pay fee for immunization. These findings are consistent with other research on access to care by Roma, both quantitative ${ }^{20}$ and qualitative ${ }^{30}$. It should also be noted that, unlike in some minority populations, we are unaware of any significant rejection of immunisation on cultural or religious grounds.

\section{Limitations}

Some factors that might be expected to influence vaccination patterns are missing in the Roma Regional survey. For instance, we did not include household income in our regressions and relied instead on an asset index which is subject to less measurement error. In addition, the Regional Roma Survey was not representative of all Roma in the twelve countries under investigation (from $78 \%$ to $90 \%$ of the entire Roma population) ${ }^{31}$. Dealing with discrimination was also challenging. From an individual perspective, the perception of discrimination is a sensitive topic. In addition, feeling discriminated against is subjective and may be subject to justification bias. This would occur if Roma respondents report being discriminated in order to justify their decision not to vaccinate their children. At the same time, according to the EU-MIDIS report on discrimination, much discrimination against Roma seems to be unreported ${ }^{32}$.

Concerning the measurement of vaccination, we have focused on the probability of receiving each type of vaccination without paying attention to the number of doses. In doing so, we may underestimate the gap between Roma and non-Roma if the former group is less likely to adhere to recommended schedules. For instance, adherence to MMR involves a 2-dose schedule. For this type of vaccine, we found a odds ratio of 0.386 without accounting for number of doses. With a definition of MMR as receipt of two-doses and using number of times as proxy of doses, the Roma gap is lower but remains nonetheless negative (the odds ratio is 0.727$)$ and statistically significant $(p<0.01)$. Among those who have been vaccinated, Roma children received a smaller number of doses for polio (1.68 against 1.76) and DPT (1.76 against 1.87). 
The final limitation is that we consider all children below 7 years whatever their age when calculating the vaccination coverage. This implies that our sample may include young infants who are not eligible for the various vaccines. At the same time, we control for child's age in our regressions which is indeed positively correlated with vaccination coverage. While we focus on differences in vaccination coverage in this paper, it would be very interesting to study the detailed timing of vaccines received by Roma and non-Roma children, respectively.

\section{Conclusion}

This study is the first to provide comparative evidence on vaccination between Roma and non-Roma children in a large number of countries. Our findings support the need to understand better the factors that influence vaccination among Roma and may ultimately contribute to improved health policies for Roma children, including measures that specifically address the factors that lead to low coverage of vaccination in this population. Our paper illustrates the complexity of the problems that Roma face. Access to vaccination cannot be discussed in isolation from other problems that Roma experience, such as poor access to health care services more broadly, low level of education, socioeconomic disadvantage, and discrimination. 


\section{References}

1. Ringold D. OMA, Wilkens E. Roma in an expanding Europe: Breaking the poverty Cycle. Washington DC: The World Bank 2005.

2. Kertesi G. KG. The Roma/non-Roma test score gap in Hungary. American Economic Review 2011: 519-25.

3. 2005-2015 DoRI. Decade declaration. Available from: http://www.romadecade.org/decade declaration. 2015.

4. Duval L, Wolff FC. "I even met happy gypsies", life satisfaction of Roma in the Balkans. Economics of Transition 2016: 1-38.

5. Cook B, Wayne GF, Valentine A, et al. Revisiting the evidence on health and health care disparities among the Roma: a systematic review 2003-2012. Int J Public Health 2013: 885-911.

6. Foldes ME, Covaci A. Research on Roma health and access to healthcare: state of the art and future challenges. Int J Public Health 2012: 37-39.

7. Hajioff S, McKee M. The health of the Roma people: a review of the published literature. J Epidemiol Community Health 2000: 864-869.

8. Parekh N, Rose T. Health inequalities of the Roma in Europe: a literature review. Cent Eur J Public Health 2011: 139-142.

9. 2005-2015 DoRI. A lost Decade? Reflections on Roma inclusion 2005-2015. Available from: http://www.romadecade.org/cms/upload/file/9809_file1_final-lostdecade.pdf

10. Nedeljkovic J, Rakic Adrovic S, Tasic G, et al. Resurgence of measles in Serbia 2010-2011 highlights the need for supplementary immunization activities. Epidemiol Infect $2016: 1121-1128$.

11. Makowka A P-SI, Szenborn L, Santibanez S, Mankerz A, Litwinska B. Measles outbreak among Roma people in Wroclaw, Poland, 2012. Polish journal of Microbiology 2014: 457-460.

12. Hegasy G, Katzner K, Helle M, et al. Description of measles D4-Hamburg outbreak in Hamburg, Germany, December 2008 to June 2009, which disproportionally affected a local Roma community. Euro Surveill 2012.

13. Melenotte C, Brouqui P, Botelho-Nevers E. Severe measles, vitamin A deficiency, and the Roma community in Europe. Emerging infectious diseases 2012.

14. Kraigher $A$, Vidovic $M$, Kustec $T$, et al. Vaccination coverage in hard to reach Roma children in Slovenia. Coll Antropol 2006: 789-794.

15. Stojanovski K, McWeeney G, Emiroglu N, et al. Risk factors for low vaccination coverage among Roma children in disadvantaged settlements in Belgrade, Serbia. Vaccine 2012: 5459-5463.

16. Stefanoff $P$, Orlikova $H$, Rogalska J, et al. Mass immunisation campaign in a Roma settled community created an opportunity to estimate its size and measles vaccination uptake, Poland, 2009. Euro Surveill 2010.

17. Orlikova H, Rogalska J, Kazanowska-Zielinska E, et al. Spotlight on measles 2010: A measles outbreak in a Roma population in Pulawy, eastern Poland, June to August 2009. Euro Surveill 2010.

18. Muscat M. Who gets measles in Europe? Journal of Infectious Diseases 2011: S353-S65.

19. Regional Roma Survey, retrieved May 1, 2016, from http://www.eurasia.undp.org/content/rbec/en/home/ourwork/sustainabledevelopment/de velopment-planning-and-inclusive-sustainable-growth/roma-in-centralandsoutheasteurope/romadata.html

20. Arora VS, Kuhlbrandt C, McKee M. An examination of unmet health needs as perceived by Roma in Central and Eastern Europe. European journal of public health 2016.

21. Cameron AC, Miller DL. A practitioner's guide to cluster-robust inference. Journal of Human Resources 2015: 317-372.

22. Filmer D, Pritchett L.H. Estimating wealth effects without expenditure data or tears: an application to educational enrollments in states of India. Demography 2001: 115-32.

23. Wilson WJ. The Declining Significance of Race: Blacks and Changing American Institutions. Chicago: University of Chicago Press 1978. 
24. Pettigrew TF. Race and Class in the 1980s: An Interactive View. Daedalus 1981 : 233-255

25. Feagin JR. The continuing significance of race: Antiblack discrimination in public places. American sociological review 1991: 101-116.

26. Hancock AM. When multiplication doesn't equal quick addition: Examining intersectionality as a research paradigm. Perspectives on Politics 2007: 63-79.

27. Oprea A. Re-envisioning social justice from the ground up: Including the experiences of Romani women. Essex human rights review 2004: 29-39.

28. Oprea A. The arranged marriage of Ana Maria Cioaba, Intra-community oppression and Romani feminist ideals transcending the "primitive culture" argument. European Journal of Women's Studies 2005: 133-148.

29. Vincze E. Socio-spatial marginality of Roma as form of intersectional injustice. Studia Universitatis Babes-Bolyai-Sociologia 2013: 217-242.

30. Boika R., Blackburn C, et al. Access to health care for Roma children in Central and Eastern Europe: findings from a qualitative study in Bulgaria. International Journal for Equity in Health 2009: 8-24.

31. Programme UND. Integrated household surveys among Roma population. Roma Inclusion Working Paper 2012.

32. Rights EUAfF. EU-MIDIS European Union Minorities and Discrimination Survey Data in Focus Report 1: The Roma 2009. 
Acknowledgements: we are indebted to two anonymous reviewers for their very helpful remarks and suggestions on a previous draft.

Funding statement: this research received no specific grant from any funding agency in the public, commercial or not-for-profit sectors.

Conflicts of interest: none declared.

Contributorship statement: Laetitia Duval and François-Charles Wolff led the study design and empirical analysis; Laetitia Duval, François-Charles Wolff, Bayard Roberts and Martin McKee all contributed to the writing-up. All authors have reviewed and approved the manuscript. 
Figure 1. Vaccination coverage by country for Roma and non-Roma combined

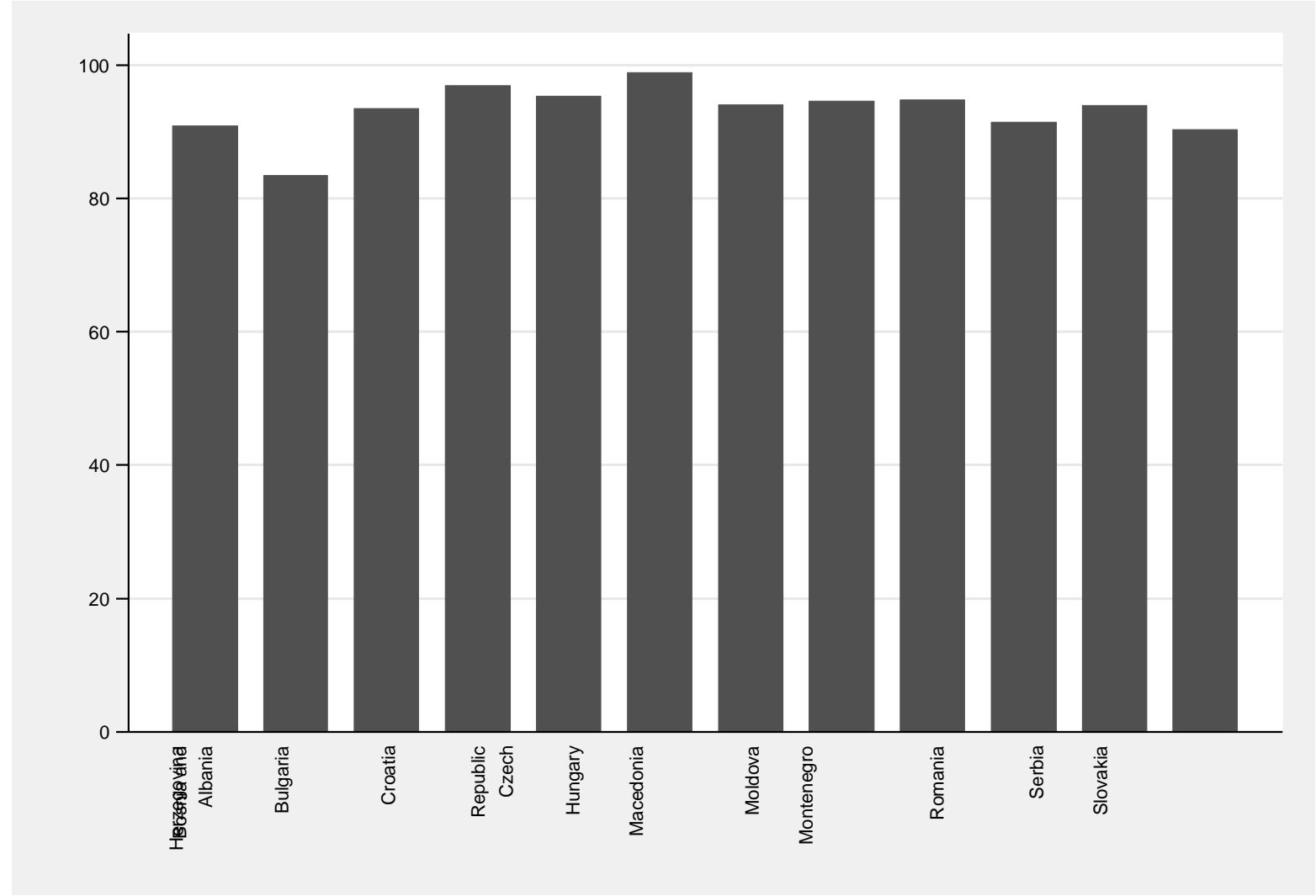

Source: authors' calculations, UNDP/WB/EC Regional Roma Survey 2011. 
Table 1. Sample size and Roma composition, by country

\begin{tabular}{|c|c|c|c|c|c|c|c|c|c|}
\hline \multirow[t]{2}{*}{ Country } & \multicolumn{3}{|c|}{$\begin{array}{l}\text { Original sample: } \\
\text { persons of all ages }\end{array}$} & \multicolumn{3}{|c|}{$\begin{array}{l}\text { Selected sample: } \\
\text { primary caregivers }\end{array}$} & \multicolumn{3}{|c|}{$\begin{array}{l}\text { Selected sample: } \\
\text { children up to } 6 \text { years old }\end{array}$} \\
\hline & Roma & Non Roma & $\%$ of Roma & Roma & Non Roma & $\%$ of Roma & Roma & Non Roma & $\%$ of Roma \\
\hline Albania & 3,533 & 1384 & 71.9 & 355 & 96 & 78.7 & 524 & 133 & 79.8 \\
\hline Bosnia and Herzegovina & 3,551 & 1130 & 75.9 & 378 & 73 & 83.8 & 657 & 87 & 88.3 \\
\hline Bulgaria & 3,058 & 938 & 76.5 & 289 & 37 & 88.7 & 414 & 48 & 89.6 \\
\hline Croatia & 3,869 & 1106 & 77.8 & 411 & 61 & 87.1 & 850 & 83 & 91.1 \\
\hline Czech Republic & 3,353 & 1049 & 76.2 & 417 & 135 & 75.5 & 625 & 174 & 78.2 \\
\hline Hungary & 3,204 & 931 & 77.5 & 322 & 55 & 85.4 & 512 & 83 & 86.1 \\
\hline Macedonia & 3,696 & 1374 & 72.9 & 337 & 81 & 80.6 & 540 & 111 & 82.9 \\
\hline Moldova & 3,163 & 934 & 77.2 & 293 & 58 & 83.5 & 454 & 67 & 87.1 \\
\hline Montenegro & 3,237 & 1046 & 75.6 & 352 & 63 & 84.8 & 654 & 88 & 88.1 \\
\hline Romania & 3,514 & 1021 & 77.5 & 366 & 49 & 88.2 & 633 & 69 & 90.2 \\
\hline Serbia & 3,645 & 1216 & 75.0 & 359 & 66 & 84.5 & 628 & 86 & 88.0 \\
\hline Slovakia & 3,511 & 1197 & 74.6 & 362 & 100 & 78.4 & 581 & 132 & 81.5 \\
\hline All & 41,334 & 13,326 & 75.6 & 4,241 & 874 & 82.9 & 7,072 & 1,161 & 85.9 \\
\hline
\end{tabular}

Source: authors' calculations, UNDP/WB/EC Regional Roma Survey 2011. 
Table 2. Characteristics of Roma and non-Roma (in \%)

\begin{tabular}{|c|c|c|c|c|}
\hline Variables & (1) All & (2) Roma & (3) Non-Roma & $(4)=(2)-(3)$ \\
\hline \multicolumn{5}{|l|}{ Child's characteristics } \\
\hline Female & 49.3 & 49.2 & 50.3 & -1.1 \\
\hline Age & 3.0 & 3.0 & 3.1 & $-0.1^{*}$ \\
\hline Birth certificate & 96.3 & 96.2 & 97.4 & $-1.2^{* *}$ \\
\hline \multicolumn{5}{|l|}{ Primary care taker's characteristics } \\
\hline Female & 92.8 & 92.6 & 94.0 & -1.3 \\
\hline Age & 29.6 & 29.3 & 31.3 & $-2.0 * * *$ \\
\hline In a couple & 86.5 & 86.3 & 88.1 & $-1.8^{*}$ \\
\hline Divorced - separated & 6.5 & 6.7 & 5.3 & $+1.5^{*}$ \\
\hline Widowed & 2.5 & 2.5 & 1.9 & +0.7 \\
\hline Single & 4.5 & 4.4 & 4.7 & -0.3 \\
\hline Household size & 6.0 & 6.2 & 4.8 & $+1.4^{* * *}$ \\
\hline No formal education & 29.1 & 33.3 & 3.1 & $+30.2^{* * *}$ \\
\hline Primary education & 25.2 & 28.2 & 6.9 & $+21.3^{* * *}$ \\
\hline Lower secondary education & 30.3 & 30.4 & 29.8 & +0.6 \\
\hline Upper/post-secondary education & 15.4 & 8.0 & 60.2 & $-52.2 * * *$ \\
\hline Paid activity - self-employed & 12.4 & 9.9 & 28.0 & $-18.1 * * *$ \\
\hline Homemaker - parental leave & 48.9 & 49.4 & 45.7 & $+3.6^{* *}$ \\
\hline Retired & 1.2 & 1.1 & 1.4 & -0.3 \\
\hline Not working - other & 37.6 & 39.6 & 24.9 & $+14.8^{* * *}$ \\
\hline Asset index & 0.0 & -0.3 & 1.9 & $-2.2 * * *$ \\
\hline Capital/district center & 32.7 & 31.8 & 38.1 & $-6.3 * * *$ \\
\hline Town & 26.0 & 25.9 & 26.4 & -0.5 \\
\hline Village/unregulated area & 41.4 & 42.3 & 35.6 & $+6.7^{* * *}$ \\
\hline Number of respondents & 8,233 & 7,072 & 1,161 & \\
\hline
\end{tabular}

Source: authors' calculations, UNDP/WB/EC Regional Roma Survey 2011.

Note: figures are expressed as percentage except for age, household size and asset index. Column (4) corresponds to meancomparison tests. Significance levels are $p<0.01\left({ }^{* *}\right), p<0.05\left({ }^{* *}\right)$ and $p<0.1\left(^{*}\right)$. 
Table 3. Roma gap in vaccination (in \%)

\begin{tabular}{|c|c|c|c|c|c|c|}
\hline Country & $\begin{array}{l}\text { (1) Any } \\
\text { vaccination }\end{array}$ & $\begin{array}{l}\text { (2) BCG } \\
\text { vaccine }\end{array}$ & $\begin{array}{l}\text { (3) Polio } \\
\text { vaccine }\end{array}$ & $\begin{array}{l}\text { (4) DPT } \\
\text { vaccine }\end{array}$ & $\begin{array}{l}\text { (5) MMR } \\
\text { vaccine }\end{array}$ & $\begin{array}{l}\text { (6) All four } \\
\text { vaccine types }\end{array}$ \\
\hline Albania & $-10.5 * * *$ & $-11.5 * * *$ & $-13.1 * * *$ & $-19.3 * * *$ & $-13.0 * * *$ & $-16.9 * * *$ \\
\hline Bosnia and Herzegovina & $-14.8^{* * *}$ & $-21.2 * * *$ & $-35.3 * * *$ & $-33.9 * * *$ & $-35.7 * * *$ & $-37.9 * * *$ \\
\hline Croatia & $-3.4^{*}$ & $-8.1^{*}$ & $-12.6 * *$ & $-9.6^{*}$ & -8.3 & $-13.6 * *$ \\
\hline Czech Republic & $-3.7 * *$ & $-19.2 * * *$ & $-19.9 * * *$ & $-25.6 * * *$ & $-28.0 * * *$ & $-30.6 * * *$ \\
\hline Hungary & -1.4 & 1.1 & $-12.4 * * *$ & $-11.4^{* * *}$ & $-14.0 * * *$ & $-17.4 * * *$ \\
\hline Montenegro & $-4.7^{*}$ & $-8.1^{* *}$ & $-22.1 * * *$ & $-19.1 * * *$ & $-21.5 * * *$ & $-21.2 * * *$ \\
\hline Romania & $-7.9 * *$ & $-21.2 * * *$ & $-23.8 * * *$ & $-25.7 * * *$ & $-31.1 * * *$ & $-18.8 * * *$ \\
\hline Serbia & $-5.5 * *$ & $-12.0 * * *$ & $-18.3^{* * *}$ & $-19.8 * * *$ & $-13.2 * *$ & $-15.1 * * *$ \\
\hline Slovakia & -0.7 & -6.9 & $-10.7 * *$ & $-7.6 * *$ & -6.3 & -6.5 \\
\hline All countries & $-5.0 * * *$ & $-10.6^{* * *}$ & $-19.2^{* * *}$ & $-20.4^{* * *}$ & $-19.7 * * *$ & $-20.3^{* * *}$ \\
\hline
\end{tabular}

Source: authors' calculations, UNDP/WB/EC Regional Roma Survey 2011.

Note: the proportion of children having received any vaccination is 10.5 lower for Roma compared to non-Roma in Albania.

The Roma gap is obtained using mean-comparison tests. Significance levels are $p<0.01(* * *), p<0.05(* *)$ and $p<0.1\left(^{*}\right)$. 
Table 4. Logit estimates of vaccination coverage (odds ratios)

\begin{tabular}{|c|c|c|c|c|c|c|c|}
\hline \multicolumn{2}{|l|}{ Variables } & $\begin{array}{l}\text { (1) Any } \\
\text { vaccination }\end{array}$ & $\begin{array}{l}\text { (2) BCG } \\
\text { vaccine }\end{array}$ & $\begin{array}{l}\text { (3) Polio } \\
\text { vaccine }\end{array}$ & $\begin{array}{l}\text { (4) DPT } \\
\text { vaccine }\end{array}$ & $\begin{array}{l}\text { (5) MMR } \\
\text { vaccine }\end{array}$ & $\begin{array}{l}\text { (6) All four } \\
\text { vaccine types }\end{array}$ \\
\hline \multicolumn{8}{|c|}{ Panel A. Without covariates } \\
\hline Roma Origin & $95 \% \mathrm{Cl}$ & $\begin{array}{l}0.325 * * * \\
{[0.214 ; 0.492]}\end{array}$ & $\begin{array}{l}0.457 * * * \\
{[0.367 ; 0.569]}\end{array}$ & $\begin{array}{l}0.344 * * * \\
{[0.283 ; 0.418]}\end{array}$ & $\begin{array}{l}0.339 * * * \\
{[0.279 ; 0.410]}\end{array}$ & $\begin{array}{l}0.386 * * * \\
{[0.325 ; 0.458]}\end{array}$ & $\begin{array}{l}0.420 * * * \\
{[0.359 ; 0.491]}\end{array}$ \\
\hline \multicolumn{2}{|c|}{ Number of observations } & 8,233 & 8,233 & 8,233 & 8,233 & 8,233 & 8,233 \\
\hline \multicolumn{2}{|c|}{ Pseudo $R^{2}$} & \multicolumn{6}{|c|}{ Panel B. With covariates } \\
\hline \multicolumn{2}{|l|}{ Roma origin } & $\begin{array}{l}0.527 * * * \\
{[0.329 ; 0.846]}\end{array}$ & $\begin{array}{l}0.704 * * \\
{[0.537 ; 0.923]}\end{array}$ & $\begin{array}{l}0.559 * * * \\
{[0.440 ; 0.710]}\end{array}$ & $\begin{array}{l}0.548 * * * \\
{[0.433 ; 0.695]}\end{array}$ & $\begin{array}{l}0.598 * * * \\
{[0.481 ; 0.744]}\end{array}$ & $\begin{array}{l}0.585^{* * *} \\
{[0.478 ; 0.716]}\end{array}$ \\
\hline \multicolumn{8}{|c|}{ Child's characteristics } \\
\hline \multicolumn{2}{|l|}{ Female } & 1.056 & $0.907^{*}$ & 0.968 & 0.947 & 0.953 & 0.954 \\
\hline \multicolumn{2}{|l|}{ Age } & $1.109 * * *$ & $1.141^{* * *}$ & $1.115^{* * *}$ & $1.121 * * *$ & $1.234 * * *$ & $1.214 * * *$ \\
\hline \multicolumn{2}{|l|}{ Birth certificate } & $2.943 * * *$ & $2.337^{* * *}$ & $2.528 * * *$ & $2.215^{* * *}$ & $1.955^{* * *}$ & $1.776^{* * *}$ \\
\hline \multicolumn{8}{|c|}{ Primary care taker's characteristics } \\
\hline \multicolumn{2}{|c|}{ Female } & 1.421 & 1.257 & 0.947 & 0.946 & 0.830 & 0.943 \\
\hline \multicolumn{2}{|l|}{ Age } & 0.998 & 1.005 & 1.005 & 1.000 & $1.007^{*}$ & $1.009 * *$ \\
\hline \multirow[t]{4}{*}{ Marital status } & In a couple & Ref & Ref & Ref & Ref & Ref & Ref \\
\hline & Divorced - separated & 1.361 & 1.172 & 0.916 & 1.074 & 1.084 & 0.959 \\
\hline & Widowed & 1.533 & 1.167 & 0.916 & 1.230 & 1.199 & 1.027 \\
\hline & Single & $0.578 * *$ & 0.887 & 1.023 & 0.800 & 0.799 & 1.023 \\
\hline \multicolumn{2}{|l|}{ Household size } & 0.977 & 0.994 & 0.979 & 0.997 & $0.970^{*}$ & 0.985 \\
\hline \multirow[t]{4}{*}{ Education } & No formal & Ref & Ref & Ref & Ref & Ref & Ref \\
\hline & Primary & $1.461^{* *}$ & $1.390 * * *$ & $1.226^{* *}$ & $1.166^{*}$ & $1.171^{*}$ & $1.164^{*}$ \\
\hline & Lower secondary & $1.728 * * *$ & $1.493 * * *$ & $1.492 * * *$ & $1.439 * * *$ & $1.427^{* * *}$ & $1.301 * * *$ \\
\hline & Upper/post-secondary & 1.258 & $1.714^{* * *}$ & $1.252^{*}$ & $1.465^{* * *}$ & 1.200 & 1.182 \\
\hline \multirow[t]{4}{*}{ Occupation } & Paid activity - self-employed & Ref & Ref & Ref & Ref & Ref & Ref \\
\hline & Homemaker - parental leave & $0.576^{* *}$ & 0.964 & 1.053 & 0.994 & 0.949 & 0.957 \\
\hline & Retired & 0.662 & $0.539 *$ & 0.688 & $0.560^{*}$ & $0.531 * *$ & $0.605^{*}$ \\
\hline & Not working - other & $0.379 * * *$ & $0.715^{* *}$ & $0.777^{* *}$ & $0.757^{* *}$ & $0.769 * *$ & $0.771 * *$ \\
\hline \multirow[t]{4}{*}{ Assets index } & Quartile 1 & Ref & Ref & Ref & Ref & Ref & Ref \\
\hline & Quartile 2 & $1.932 * * *$ & $1.292^{* *}$ & $1.244^{* *}$ & $1.350 * * *$ & $1.296 * * *$ & $1.274^{* * *}$ \\
\hline & Quartile 3 & $1.875^{* * *}$ & $1.549 * * *$ & $1.431 * * *$ & $1.789 * * *$ & $1.659 * * *$ & $1.401 * * *$ \\
\hline & Quartile 4 & $2.510 * * *$ & $1.987 * * *$ & $2.181 * * *$ & $2.049 * * *$ & $2.085^{* * *}$ & $1.813^{* * *}$ \\
\hline \multirow[t]{3}{*}{ Location } & Capital/district center & Ref & Ref & Ref & Ref & Ref & Ref \\
\hline & Town & $1.633^{* * *}$ & $1.342 * * *$ & 1.039 & 0.964 & 0.935 & 0.993 \\
\hline & Village/unregulated area & $1.313^{*}$ & 0.944 & $0.848^{*}$ & $0.730 * * *$ & $0.665^{* * *}$ & $0.755^{* * *}$ \\
\hline \multicolumn{2}{|c|}{ Country dummies } & YES & YES & YES & YES & YES & YES \\
\hline \multicolumn{2}{|c|}{ Number of observations } & 8,233 & 8,233 & 8,233 & 8,233 & 8,233 & 8,233 \\
\hline \multicolumn{2}{|l|}{ Pseudo $\mathrm{R}^{2}$} & 0.116 & 0.095 & 0.089 & 0.108 & 0.114 & 0.099 \\
\hline
\end{tabular}

Source: authors' calculations, UNDP/WB/EC Regional Roma Survey 2011.

Note: standard errors (not reported) are clustered at the household level (5115 clusters). Significance levels are $p<0.01$

$(* * *), p<0.05\left(^{* *}\right)$ and $\mathrm{p}<0.1\left(^{*}\right)$. 
Table 5. Logit estimates of vaccination coverage regard to health care access (odds ratios)

\begin{tabular}{|c|c|c|c|c|c|c|}
\hline Variables & $\begin{array}{l}\text { (1) Any } \\
\text { vaccination }\end{array}$ & $\begin{array}{l}\text { (2) BCG } \\
\text { vaccine }\end{array}$ & $\begin{array}{l}\text { (3) Polio } \\
\text { vaccine }\end{array}$ & $\begin{array}{l}\text { (4) DPT } \\
\text { vaccine }\end{array}$ & $\begin{array}{l}\text { (5) MMR } \\
\text { vaccine }\end{array}$ & $\begin{array}{l}\text { (6) All four } \\
\text { vaccine types }\end{array}$ \\
\hline Roma origin & $0.556 * *$ & $0.694 * * *$ & $0.566 * * *$ & $0.571^{* * *}$ & $0.613^{* * *}$ & $0.596 * * *$ \\
\hline $95 \% \mathrm{Cl}$ & {$[0.348 ; 0.890]$} & {$[0.528 ; 0.913]$} & {$[0.443 ; 0.722]$} & {$[0.449 ; 0.726]$} & {$[0.491 ; 0.766]$} & {$[0.485 ; 0.732]$} \\
\hline Doctor to approach when needed & $2.006 * * *$ & $1.547 * * *$ & $1.605 * * *$ & $2.085 * * *$ & $1.760 * * *$ & $1.809 * * *$ \\
\hline Feel safe in regards health protection & $1.408 * *$ & $1.274^{* *}$ & $1.414^{* * *}$ & $1.188^{*}$ & $1.238^{* *}$ & $1.225^{* *}$ \\
\hline Cannot afford purchasing medicine prescribed & 1.029 & $1.295 * * *$ & $1.132 *$ & 0.995 & 0.992 & 1.037 \\
\hline Discriminated against because of ethnicity & $0.723 * *$ & 0.988 & 0.865 & $0.782^{* *}$ & 0.890 & 0.910 \\
\hline Discriminated against because of other reasons & 0.966 & 0.843 & $1.346^{*}$ & $1.358^{*}$ & 1.246 & 1.180 \\
\hline Control variables & YES & YES & YES & YES & YES & YES \\
\hline Number of observations & 8,233 & 8,233 & 8,233 & 8,233 & 8,233 & 8,233 \\
\hline Pseudo $\mathrm{R}^{2}$ & 0.137 & 0.105 & 0.100 & 0.121 & 0.123 & 0.108 \\
\hline
\end{tabular}

Source: authors' calculations, UNDP/WB/EC Regional Roma Survey 2011.

Note: standard errors (not reported) are clustered at the household level (5115 clusters). Significance levels are $p<0.01$

$(* * *), p<0.05(* *)$ and $p<0.1\left(^{*}\right)$. Each model includes the set of individual and household characteristics included in Table 4. 